УДК 94(479.24)

\title{
ИСТОРИЯ ОТКРЫТИЯ И ДЕЯТЕЛЬНОСТИ БАКИНСКОЙ ОФИЦЕРСКОЙ ШКОЛЫ МОРСКОЙ АВИАЦИИ
}

В предлагаемой статье на основе архивных материалов, периодической печати и дополнительной литературы рассматривается необходимость и причины открытия Офицерской школы морской авиации в Баку в годы первой Мировой войны. Отмечено, что в начале $\mathrm{XX}$ века армия царской России испытывала недостаток в авиационных офицерских кадрах. Поэтому для их подготовки началось создание авиационных военно-учебных заведений. В годы первой Мировой войны многие вузы (Петербург, Москва, Севастополь, Киев) перешли на обучение по программе военного времени. В статье обосновывается необходимость и цель подготовки морских военных летчиков непосредственно в Баку, а именно: Бакинский порт, техническое оснащение которого создавало весьма благоприятные условия для размещения здесь школы Морской Авиации. Автор отмечает значительную роль Бакинской городской думы и Городской управы в осуществлении деятельности и финансовой поддержки этой школы. Говорится об испытании летательных аппаратов и новых средств для морской авиации. Обращается внимание на подготовку летчиков боевым видам - разведке и корректировке артиллерий- ского огня, на обучение личного состава школы метанию зажигательных и разрывных бомб, а также на оказание помощи моряков Школы в подавлении беспорядков, так называемых «голодных бунтов», или «женских бунтов» в Баку в феврале 1916 года. В статье показана роль Бакинского технического училища и его помощь по изготовлению новых механизмов и других технических новинок для использования в морской авиации.

В статье также приводятся имена первых в истории азербайджанской авиации азербайджанских летчиков, а также имена первых летчиц-азербайджанок. Значительную роль в подготовке авиационных кадров сыграли первые Всероссийские авиационные съезды. В связи с образованием Азербайджанской Демократической Республики правительство принялось за организацию своих вооруженных сил, и, в частности, своей национальной авиации.

Ключевые слова: Петроград, Бакинская городская дума и Бакинское городское самоуправление, морская авиация, школа, летчики, летательные аппараты, Бакинское Техническое училище

\section{BAKU OFFICER SCHOOL OF NAVAL AVIATION: FROM THE HISTORY OF ESTABLISHMENT AND ACTIVITY}

The article studies the reasons for establishment of Officer School of Naval Aviation in Baku in the years of World War I. The study is based on archival materials, periodicals and additional literature. It should be noted that in the beginning of the XX century the army of imperial Russia lacked aviation officers. During World War I many higher educational institutions (St. Petersburg, Moscow, Sevastopol, Kiev) shifted to the training under the program of wartime. The study draws attention to the need to establish a special school for retraining officers in the artillery observer pilots. The article substantiates the necessity and the purpose of training naval military pilots in Baku. The Baku Port was chosen for the uninterrupted training of military pilots, as the largest port of the Russian Empire for freight turnover. The technical equipment of the port provided favorable conditions for the establishment of the Naval Aviation School in

В ноябре 2018 г. исполнилось 103 года со дня открытия в Баку Отделения офицерской школы морской авиации. Но этому предшествовали определенные обстоятельства.

В царской России с 1910 г. началось создание авиационных военно-учебных заведений для
Baku. The author notes a significant role of the Baku City Council and City Government in implementation of activity and financial support for this school. The article shows the role of the Baku Technical School and its assistance in the manufacture of new mechanisms and other technical innovations for naval aviation.

The article also features the names of the first Azerbaijani pilots in the history of Azerbaijani aviation, as well as the names of the first female Azerbaijani pilots. A significant role in the training of aviation personnel was played by the first All-Russian Aviation Congresses. Due to the formation of the Azerbaijan Democratic Republic, the government set to organize its armed forces, in particular, its national aviation.

Key words: Petrograd, Baku City Council and Baku municipal government, sea aircraft, school, pilots, aircraft. Baku Technical School.

подготовки офицеров-летчиков. В 1911 г. особым указом Николай II утвердил звание «Военный летчик Российской империи» и все учащиеся авиационных вузов стали получать это звание по выпуску [52, с. 527]. Накануне первой Мировой войны происходят изменения в деятельности 
существовавших к тому времени авиационных военно-учебных заведений. Это было вызвано тем, что армия царской России испытывала недостаток в авиационных офицерских кадрах. До конца 1914 г. эти вузы (Петербург, Москва, Севастополь, Киев), перешли к обучению по программе военного времени. С подготовкой военных летчиков возникла необходимость и в подготовке летчиков-наблюдателей. Одновременно в конце 1915 г. возник вопрос о пополнении авиации специалистами, знакомыми с аэрофотографией, и имеющими артиллерийское образование. Такая ситуация привела к необходимости создания специальной школы для переквалификации артиллерийских офицеров в летчиков-наблюдателей [52, с. 527]. И уже 8 июля 1915 года была открыта Петроградская Офицерская Школа Морской Авиации - ПОШМА, ставшая первым авиационно-морским военно-учебным заведением. Вслед за этим состоялось открытие аналогичных школ морской авиации в других городах, где морские летчики проходили подготовку в течение 4 месяцев [52, с. 529].

Но уже к осени 1915 г. школа не могла обеспечить все те потребности, ради чего, собственно она и была открыта. И этому было объективное объяснение. Причина заключалась в том, что в зимний период Балтийское море было непригодно как для целенаправленной работы по подготовке морских (военных) летчиков, так и для учебных полетов гидропланов. Именно в силу того что Российский флот испытывал острую нужду в военных летчиках, Морской Генеральный Штаб (МГШ) и Отдел Воздушного Флота решили перевести эту школу на юг России. Для этого руководством Морского Генерального Штаба (вице-адмирал А. И. Русин с 1914 г.) были предприняты некоторые шаги, направленные на исправление сложившейся ситуации. Прежде всего, было решено открыть в зимнее время в одном из не замерзающих портов отделение офицерской школы морской авиации. С этой просьбой руководство МГШ обратилось в Отдел воздушного фолота высочайше учрежденного Особого Комитета (письмо от 16.9.1915 г. за № $14048 / 3987$ и от 19.9.1915 г за № 7522) [11, л. 1]. Выбор пал на город Баку и Бакинский порт. Первоначально данное решение рассматривалось как временное и преследовало цель «обеспечения бесперебойной подготовки к весне 1916 года морских летчиков» [20; 48, л. 99]

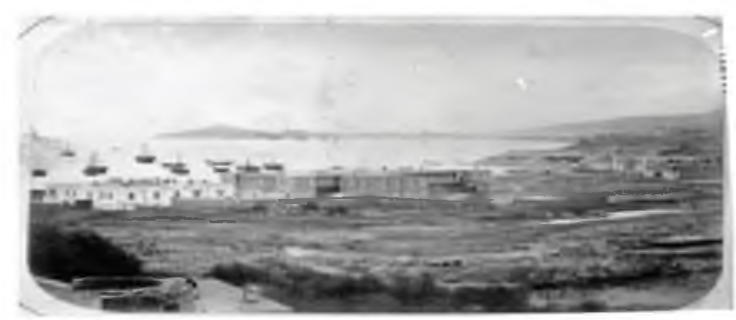

Вид на бакинскую пристань со стороны Дворца Ширваншахов

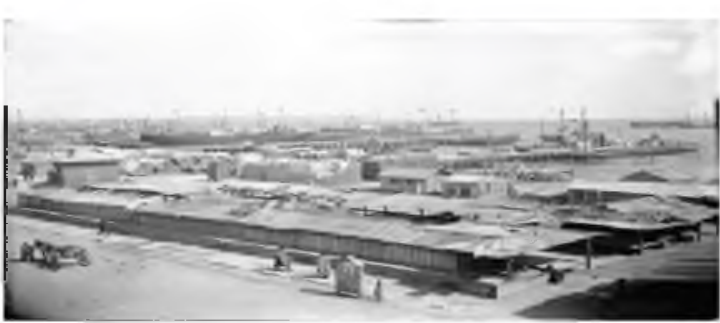

\section{Бакинская пристань}

Данный выбор Баку был обусловлен еще несколькими причинами, а именно: климатическим фактором (Каспийское море не замерзало); отсутствием активных боевых действий на Каспийском море и в акватории Бакинского порта (в отличие от Черного моря); удаленностью Баку от театра военных действий в годы первой Мировой войны; Баку, будучи крупным нефтепромышленным центром, к началу $X X$ в. являлся и городом с развитым судоходством (судоходство стало развиваться с созданием государства Ширваншахов в IX веке; к этому времени относится и строительство торгового фллота Ширваншахов и морского порта в Баку), где располагалось Военно-Морское командование Каспийской флотилией. В 70-80 годах XIX века в Баку были использованы первые нестеналивные пароходы - знаменитые нобелевские «Зороастр», «Магомед», «Будда», «Моисей», ставшие прообразом современных танкеров. А к началу XX В. Бакинский порт являлся уже самым крупным портом Российской Империи по грузообороту [2; 18, с. 14-23]. Таким образом, техническое оснащение порта создавало весьма благоприятные условия для размещения школы Морской Авиации именно в Баку.

B самом начале XX века в Баку и Евлахе были построены и сданы в эксплуатацию аэродромы, а также широкий размах в Баку получило авиамоделирование $[23$, с. 8]. По сообщению периодической печати, еще в 1910 г. в Баку над Балаханским шоссе на аэроплане типа «Фарман» русским авиатором Сергеем Уточкиным были осуществлены 4 показательных полета. В дальнейшем эти полеты на самолетах стали приобретать периодический характер [6].

К этому времени уже были известны имена первых двух азербайджанских авиаторов, навечно вошедшие в историю авиации Азербайджана. Это Алибей Самедбей оглу Вердиев и Фаррух ага Мамед Керим оглу Гаибов. А. С. Вердиев получил образование авиаинженера во Франции. Во время первой Мировой войны проходил подготовительные курсы во французской школе авиапилотирования, давал уроки полета курсантам училища, выпускником которого он был. В 1916 г. он был удостоен Международной федерацией авиации диплома пилота-авиатора. Также работал инструктором, регулирующим испытательные полеты новых самолетов, и, как инженер-механик, контролировал исправность самолетов. Вернувшись в 1918 г. в Азербайджан, А. С. Вердиев продолжил свою профессиональную деятельность. 
Ф. М. Гаибов был первым военным авиатором в истории азербайджанской авиации. Поручик Ф. М. Гаибов в начале Первой Мировой войны в составе российской авиации, принимавший участие в боевых действиях на Западном фронте, был известен как умелый пилот-стрелок в составе экипажа бомбардировщика «Илья Муромец-16». 12 сентября 1916 г. 25-летний поручик Ф. М. Гаибов в неравном бою, сбив четыре вражеских самолета, погиб вместе с экипажем [17, с.180, 477; $22 ; 23$, c. $10 ; 46]$

Кроме того, Баку был выбран и по настоянию Его Императорского Высочества князя Александра Михайловича (пред. Особого комитета...), приказавшего «исполнить просьбу Морского Генерального Штаба об открытии школы морской авиации именно в Баку» [49, л. 1]. Тем самым, с переводом летной школы в Баку «балтийцы были освобождены от обузы обучения летчиков на гидропланах» $[44 ; 50$, л. 11$]$.

На должность начальника Бакинского отделения Офицерской Школы Морской Авиации (БООШМА) Отдела Воздушного Флота организатором и первым директором Петроградской Офицерской Школы Морской Авиации старшим лейтенантом А. А. Тучковым был рекомендован капитан I ранга в отставке Андрей Александрович Янович. Особый Комитет, учрежденный для усиления военного фллота на добровольные пожертвования (состоял из отделов морского, воздушного фрлота, комиссии по сбору пожертвований, финансового), обратился к Бакинскому градоначальнику об оказании содействия капитану I ранга в отставке А. А. Яновичу в деле устройства и оборудования в Баку офицерской школы морской авиации [11, л. 2-2 об, 3]. 1 октября 1915 г А. А. Янович приступил к работе.

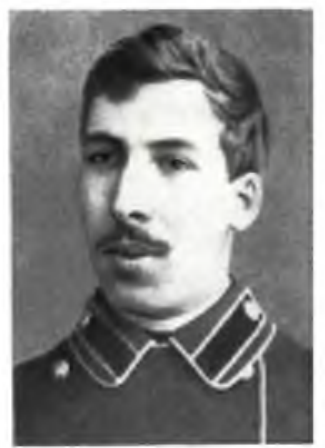

М. Г. Гаджинский (18751931) - завотделом строительства Бакинской городской управы, гражданский инженер, выпускник Петербургского технологического университета.

Видный государственный и политический деятель Азербайджанской Демократической Республики

Большой вклад в деле открытия и оборудования Бакинского отделения офицерской школы морской авиации школы внесли Бакинская городская управа в лице ее руководителя Мамедгасана Гаджинского (выпускника Петербургского технологического института), Бакинский городской голова Л. Л. Быч, Бакинский градоначальник полк. П. И. Мартынов, капитан 1 ранга, контр-адмирал Е. В. Клюпфель, назначенный в конце 1913 года директором маяков и лоций Каспийского моря и командиром Бакинского порта [25, с. 625] и на- чальник Бакинского торгового порта капитан ранга в отставке П. А. Данилов, комендант железнодорожного и водного участка станции Баку ротмистр Редриков, благодаря которому БООШМА имела постоянную и своевременную возможность получать и отправлять грузы 8 [47].

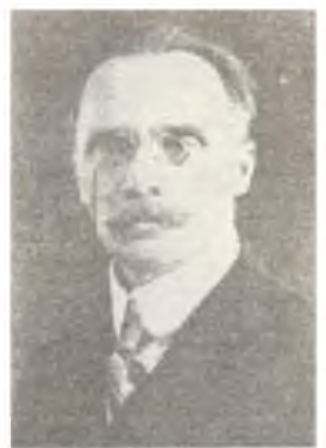

Л. Л. Быч (1870-1945) Бакинский городской голова с 1912-1917 гг.

Так, например, в письме на имя начальника БООШМА сообщалось, что на заседании Бакинской Городской управы (31.10.1915г., №1209/19242) было принято постановление «об отводе участка городской земли под ангары для гидроаэропланов Бакинского отделения ОШМА» [11, л. 2]. На очередном заседании Бакинской городской думы (вып. из журн. 27.10.1915 г., №26), а также в Докладе Бакинской Городской Управы от 7 октября 1916 года по строительному отделению (прил. №5) был рассмотрен вопрос об отводе в районе бульвара участка земли под Авиационную школу $[12$, л. 4a].

12 ноября 1915 года первый эшелон с офицерами и нижними чинами прибыл в Баку. Как сообщал «Каспий», «школа являлась учреждением общественным, так как она и весь отдел воздушного флота комитета по усилению военного флота существовал на жертвуемые обществом средства» [36], а также находится под покровительством ЕИВ Великого князя Александра Михайловича. В школу могли поступить и сухопутные летчики. Все оборудование Школы было закончено к 22 ноября 1915 года. Министерство торговли и промышленности любезно предоставило для команды школы учебную шхуну Бакинского мореходного училища «Али-Абад". Были получены все необходимые аппараты и различные принадлежности грузовые и пассажирские автомобили, мотоциклеты, аппараты для полетов, из Петрограда получен был моторный быстроходный катер [22]

22 ноября 1915 года состоялось открытие Бакинского отделения Петроградской офицерской школы Морской Авиации. Освещение школы и молебен торжественно совершал епископ Григорий Бакинский. На открытие были приглашены «все власти, представители Городского самоуправления, по 20 человек учащихся при своем начальстве от каждого из учебных заведений Баку, произнесены здравицы в честь представителей царствующей фрамилии и были демонстрированы первые публичные полеты» $[11$, л. 3]. 


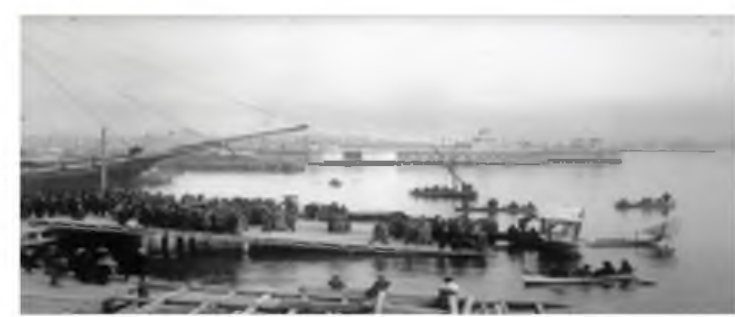

Подготовка аппарата к пробному полету в день открытия Бакинской офицерской школы морской авиации

23 ноября 1915 года было получено поздравление от Его Императорского Величества Николая II: «Желаю от всего сердца Божьего благословения и полного успеха вновь открытому отделению школы морской авиации в Баку и благодарю весь личный состав за готовность послужить по примеру наших доблестных летчиков» $[11$, л. 3]. Также была получена телеграмма от великого князя Александра Михайловича, в котором «выражалась благодарность за посланную А. Яновичем телеграмму и всему личному составу школы, а также уверенность, что летчики, вышедшие из молодой школы, будут доблестно служить...) [37]. Поздравление по случаю открытия БООШМА было получено от главного начальника Кавказского военного округа генерал-лейтенанта С. В. Вольского, обещавшего при удобном случае посетить школу [38]. В этот же день, 23 ноября 1915 г. начались учебные полеты. Команда Бакинского отделения насчитывала 160 человек. Наряду с офицерами, в Школе обучались и нижние чины авиационные унтер-офицеры, авиационные кондукторы, охотники (добровольцы) и матросы.

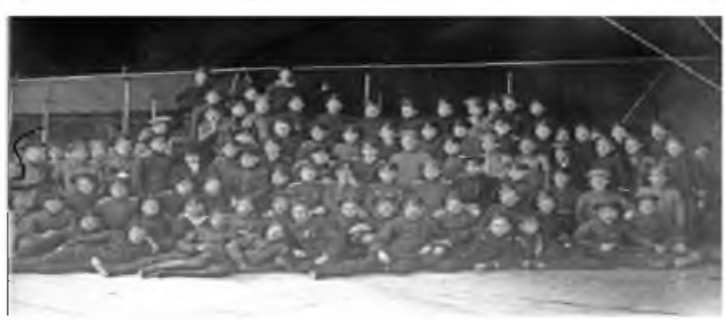

Личный состав Бакинской офицерской школы Морской авиации

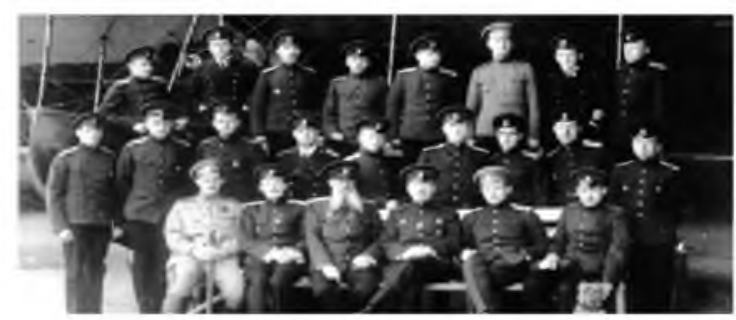

Офицерский состав Бакинской офицерской школы Морской авиации

Второй эшелон был отправлен из Петербурга 30 ноября и прибыл в Баку 14 декабря 1915 г. Таким образом, большая часть курсантов прибыла тремя партиями 10-12 ноября, 12-14 декабря и 31 декабря 1915 г., но некоторые прибыли отдельно после 16 января 1916 г. В декабре 1915 г. в Баку побывал известный летчик, инструктор-лейтенант Б. Р. Миклашевский [28].

Офицерские школы морской авиации были рассчитаны в среднем на 20 человек каждая. Однако в условиях военного времени готовили по 27-35 человек в наборе [52, с. 530]. На 40 человек, одновременно проходивших обучение в БООШМА, постоянный состав школы насчитывал 158 человек. Аналогичное организационное устройство имели и военные авиационные школы $[9$, c. $62-67]$.

В течение ноября-декабря 1915 года в Баку были отправлены аэропланы Щетинина, прибывшие в город только в январе 1916 года [49]. Как следует из отчета А. А. Яновича, в распоряжении Школы было «...8 учебных аппаратов двух систем: «типа M-5» и «типа FBA». Весной 1916 г. школа получила один аппарат Кертисса, но полётов на нём было сделано мало...». Обучение, в основном, осуществлялось на гидросамолетах конструкции Григоровича М-5, M-9, M-11. Всего на учете в Бакинском отделении школы по ведомости авиационного имущества числилось 14 летательных аппаратов, в основном аппараты Щетинина (приказ по БООШМА №121 от 16.01.1916 г.). А для организации обучения летчиков бомбометанию 5 марта 1916 г. во временное пользование был предоставлен остров «Песчаный», расположенный в районе Бакинского градоначальства.

После окончания оборудования этой школы и посещения её городским головой Л. Л. Бычем начальник БООШМА капитан I ранга А. А. Янович обратил его внимание на решение ряда вопросов, а именно: сооружения легкой постройки для кают-компаний офицеров с устройством в них электроосвещения и установкой переносимых печей; проведения электричества на дополнительно приспособленную для нужд школы Таможенную пристань и некоторых мелких работ. Со своей стороны, Л. Л. Быч согласился произвести все эти работы, а А. Янович просил ускорить все вышеотмеченные работы [29].

На заседании портового присутствия под председательством А. Ф. Данилова обсуждалось ходатайство Бакинской городской управы о разрешении засыпки водного пространства 1700 кв. саж. между Каменной пристанью и пристанью №10 общества «Кавказ и Меркурий» для офицерской школы морской авиации.

В принятом постановлении отмечалось, что место, выбранное для помещения авиационной школы, крайне стеснительно для торгового судоходства..., что школа переведена в Баку временно и во всей бухте нет другого более подходящего для нее места. Проект Городской управы и смета на засыпку водного пространства обошлись городу в 68088 рублей [27]. Вопрос о засыпке был одобрен, при условии, что «город в последствие не будет просить возмещения казной произведенных им по засыпке расходов» [30]. На первоначальное оборудование помещения для 
школы авиации выделен технический персонал, а Городская дума выделила аванс 6 т.р. на работы по приспособлению Каменной и Таможенной пристани под школу с тем, чтобы эта сумма в будущем была возвращена городу. Но поскольку этих средств не хватило, то управа на свой риск продолжила дальнейшее ассигнование, доведя их до 17 т.р. [32].

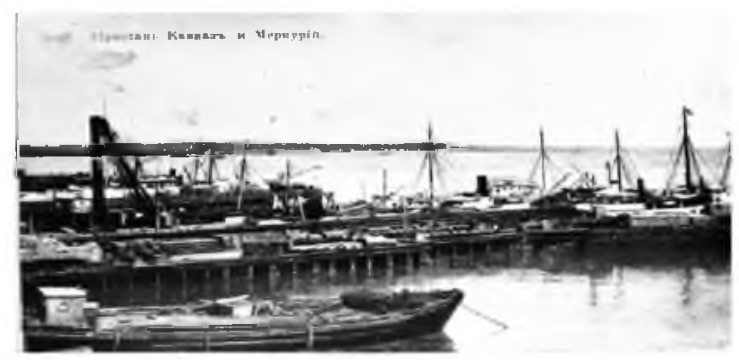

Пристань «Кавказ и Меркурий»

Хотя официальное название школы «Офицерская", тем не менее, наряду с офицерами, в ней обучались и нижние чины - авиационные унтер-офицеры, авиационные кондукторы, охотники (добровольцы) и матросы. Нижние чины, допущенные в 1916 г. к обучению в морской авиации на звание морского летчика, имели особое положение. Многие охотники 2-го и 3-го разрядов проходили обучение для дальнейшей службы в качестве младших авиационных специалистов механиков, мотористов, техников по обслуживанию гидропланов

За время деятельности отделения школы, с 23 ноября 1915 г. по 27 апреля 1916 г. в нем обучались 40 офицеров и 17 нижних чинов, имеющих право на производство в офицеры, а также 6 нижних чинов, этого права не имеющих. Из них было выпущено 20 морских летчиков офицеров и один нижний чин [23]. Вся деятельность Школы была подчинена одной цели - подготовке и выпуску квалифицированных морских летчиков для участия в боевых действиях первой Мировой войны.

Большую роль в подготовке кадров для авиации флота сыграл первый официальный документ отечественной морской авиации, а именно: «Положение о службе авиации в службе связи» [52, с. 529]. Документ также определял, что подготовка нижних чинов к службе в качестве авиационных специалистов осуществляется на флотах при одной из станций 1-го разряда в каждом воздушном районе [52, с. 530].

9 (22) января 1916 года в Баку были закончены испытания гидросамолета М-9 Д. П. Григоровича, начавшиеся 25 декабря 1915 года. Через два дня 11 (24) января 1916 года по итогам испытания M-9 специальной комиссией Бакинского порта был подписан акт. М-9 летал в Баку до 24 марта (6 апреля) 1916 года, а затем был передан в Севастополь. Проводившиеся в Баку испытания М-7 Д. П. Григоровича из-за успеха М-9 были приостановлены. Руководство авиационной школы через местную печать уведомило посетителей, которым был разрешен осмотр школы по утрам и в воскресенье, что к полетам для публики они допускаться временно в течение 1-1,5 месяцев не будут [7; 31]

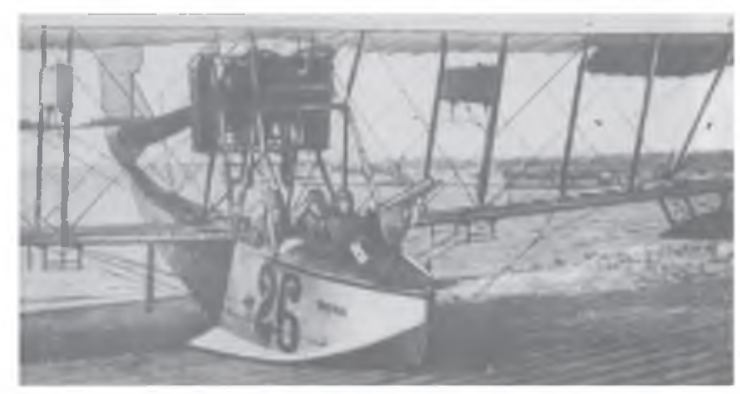

Летающая лодка М-9 Д. П. Григоровича

Главными задачами морской авиации на протяжении всей первой Мировой войны были разведка и корректировка артиллерийского огня. Поэтому основное внимание уделялось подготовке летчиков именно этим боевым видам. Для этой цели Управлением рыбными промыслами во временное пользование Школе авиации был передан полигон на о. Песчаный в Бакинской бухте, где шло обучение личного состава школы метанию бомб как зажигательных, так и разрывных [35].

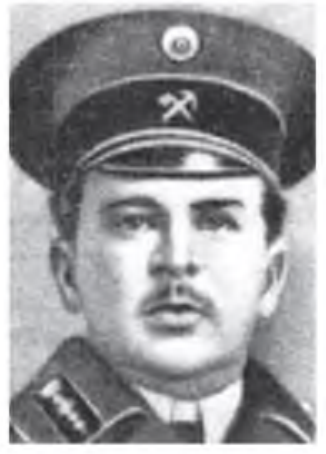

Д. П. Григорович (18831938) - Российский и советский авиаконструктор,специалист по гидросамолётам

В этой связи А. Янович просил градоначальника П. И. Мартынова организовать оповещение окрестного населения об опасности для тех, кто мог оказаться на о. Песчаный во время проведения занятий [35]. Кроме того, на о. Песчаном было много змей, поэтому А. А. Янович издал специальный приказ, чтобы команды туда выезжали только в высоких сапогах.

В течение января-марта 1916 года здесь же в Баку проходили испытания аэроглиссера №2 Голенищева-Кутузова, построенного на заводе С. С. Щетинина в конце ноября 1915 г. 27 апреля 1916 г. занятия и полеты в БООШМА были завершены, и лишь осенью 1916 г. Бакинское отделение школы возобновило свою работу

30 апреля (13 мая) 1916 года был издан приказ (№ 222) о формировании Российского императорского военно-воздушного флота, что способствовало проведению единой технической политики, разработке тактики и стратегии авиации и дальнейшему ее развитию. Одновремен- 
но производились испытания новой техники для морской авиации, а именно: два новых аппарата типа «Морской-9» и «Морской-10», а также новые модели аэропланов Григоровича, Лебедева и некоторые другие. Этим занимались как штатные старшие инструкторы Школы, так и прикомандированные опытные летчики, в числе которых в январе 1916 года в Баку находился известный летчик, лейтенант С. А. Лишин.

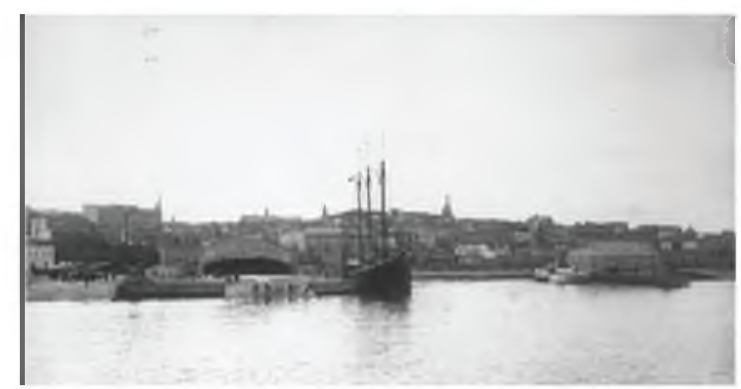

Общий вид Бакинской Офицерской Школы

Морской Авиации со стороны моря

В истории БОШМА интересен такой факт. В результате вздорожания цен на предметы первой необходимости с 14-16 февраля 1916 г. в Баку произошли так называемые «голодные бунты», или «женские бунты», к которым затем присоединились и мужчины. Согласно архивным материалам, «толпа женщин двинулась с Базарной улицы (ныне пр. Азербайджан) к Александро-Невским рядам и начали громить здесь мясные ряды, бакалейные и гастрономические магазины, затем женщины перешли к разгрому пассажа» $[15$, л. 2]. Поскольку бунты не прекращались, городские власти вынуждены были вызвать против женщин взвод казаков и конных городовых даже полторы тысяч солдат было недостаточно для охраны города Баку и разгона толпы женщин $[13$, л. 1]. На чрезвычайном заседании городских властей многие требовали принять карательные меры и вызвать новые казачьи отряды. Была вызвана помощь второго сводного полка Кубанского казачьего войска [13, л. 15]

В такой обстановке по просьбе капитана Морского порта г. Баку контр-адмирала Е. В. Клюпфеля в оказании помощи Бакинскому гарнизону по ликвидации начавшихся в Баку в начале 1916 года беспорядков принимали участие 18 офицеров этой Школы. В каждый из шести воинских подразделений пехоты и казаков были распределены от 2-х до 5-ти офицеров Школы [12; 21, с. 51]. А мичман В. М. Горяинов предложил использовать школьный грузовик, установив на него пулеметы. Эта идея принесла большую пользу, что позже особо было отмечено в приказе А. А. Янови4а. Августейший Наместник Императора на Кавказе Его Высочество Николай Николаевич (через Клюпфеля) «горячо благодарил моряков Школы за помощь в подавлении беспорядков в Баку» [53] 52. 17 февраля 1916 г. бунт был фактически подавлен и офицеры вернулись в Школу к своим непосредственным обязанностям - службе, уче- бе, полетам и т.д. [53] 52. В свободное же время коллектив Школы отдыхал.

Согласно архивному источнику, среди арестованных, как мужчин, так и женщин, участвовавших в бунте, не было азербайджанцев. В основном это были русские и армянские женщины. Двое арестованных мужчин были из России и двое армян [3, с. 87-88; 14, л. 2об. - 3]. Азербайджанские женщины в погромах не участвовали. Дело в том, что азербайджанские женщины не ходили на базар: материальное обеспечение семьи полностью возлагалось на мужчин, как и другие обязанности. В оправдание русских и других женщин ошибочно высказывалось мнение, что азербайджанские мужчины не были мобилизованы на войну и могли материально обеспечить свою семью, в то время как христианские женщины, мужья которых были на войне, были относительно в худшем положении, хотя государство выплачивало им пособия. Эта ошибочная версия опровергается тем обстоятельством, что с начала 1916 г. по решению правительства мусульмане России также стали призываться в армию. И надо заметить, что положение азербайджанских женщин было еще хуже других женщин, так как государство не выплачивало мусульманкам пособия. И этот вопрос был поднят в статье Таги Шахбази «Новое положение и наши женщины», опубликованной в газете «Ачыг сез» («Открытое слово») [54]. Вопрос о февральских событиях в Баку был предметом обсуждения на нескольких февральско-мартовских заседаниях IV Государственной думы [8; 24; 33; 34; 39; 40; 41]

Еще один примечательный факт из жизни БОШМА, усматриваемый из Рапорта начальника БООШМА ОВФ капитана 1-го ранга А. А. Яновича от 30 апреля 1916 г. По указанию Высшего Начальства командиром Бакинского порта контр-адмирал Е. В. Клюпфелем в феврале 1916 г. была организована важная экспедиция в Иран, связанная с военными действиями в ходе первой Мировой войны. Школа выделила один из лучших аппаратов с запасными частями, которым управлял морской летчик мичман П. П. Величковский, за что был награжден боевой наградой.

Учебный процесс в БООШМА строился с учетом всех технических нововведений, появлявшихся к этому времени в авиации. В начале апреля 1916 года в Бакинскую Школу был командирован по делам радиотелеграфии старший лейтенант Стогов. Занятия по приему телеграмм на слух в кают-компании шхуны «Али-Абад» вел заведующий радиотелеграфными станциями Каспийского моря мичман В. В. Сакович с помощью 2-х телеграфистов. Занятия продолжались до отъезда Школы в Петроград в конце апреля 1916 года.

В ходе первой Мировой войны все внимание сосредоточивалось на новых видах вооружения и военной техники. И если, например, для Германии главным был подводный флот, то царская Россия все внимание сосредоточивала на развитии и становлении отечественной авиации. Значительную помощь по изготовлению новых меха- 
низмов и других технических новинок оказывало Бакинское техническое училище.

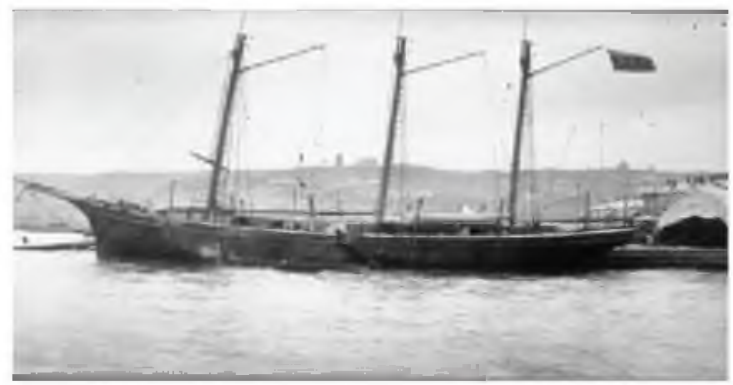

Шхуна «Али Абад» на пристани Бакинской офицерской школы авиации со стороны моря

А. А. Яновичзаботился и о материальном благополучии своих работников. Так, 4 февраля 1916 г он «просил Особый Комитет выделить деньги, чтобы повысить жалование казначею П. П. Григорьеву, делопроизводителю и бухгалтеру, сопровождая просьбу самыми похвальными характеристиками всех троих. Их зарплата составляла по 50 руб., дополнительно еще по 100 руб. в месяц на каждого, итого 150 руб. на человека» [49, л. 1-2]. Так же Янович просил о повышении зарплаты шоферу Бортникову с 30 до 100 руб.

Значительную помощь Школе авиации оказывала Бакинская городская дума и Управа. Об этом, в частности, писал и сам начальник Школы А.А. Янович: «Город часто и безвозмездно проводил многие работы: была отгорожена Каменная пристань на Набережной (напротив нынешнего здания Государственной нефотяной компании Азербайджанской Республики - ГНКАР на пл. Азнефоть, основанной 13 сентября 1992 года со штаб-квартирой в Баку) деревянным забором, построен открытый гараж на 4 автомобиля, мастерские и склады, отремонтировано здание канцелярии, лазарет и школьная фотолаборатория, проведен телефон, оборудована метеостанция, организованы противопожарные меры» [49, л. 2]. И самое главное, как отмечалось в Отчете капитана I ранга, командира БООШМА А. А. Яновича «были устроены спуски (не менее 14 метров) к воде для гидропланов, каждый из которых состоял из 25-30 свай и обошелся городу в несколько тысяч рублей, и для чего было выделено много дорогостоящего дерева для свай и настилов. Городом было проведено электричество (оплата за счет города) во все службы Школы, включая шхуну «Али-Абад», удачно приспособленная для проживания команды Школы» $[48, л$. 99]. По словам А.А. Яновича, «морские летчики в долгу у города не остались, и через некоторое время защищали его с воздуха... » [48, л. 99].

Школьной метеостанцией руководил специально командированный для этого вольноопределяющийся охотник (иначе - доброволец) Павел Введенский, которому помогал делопроизводитель Зейдон Ландау. Причем наблюдения передавались сначала в Главную физическую, потом в Романовскую Обсерваторию и имели са- мостоятельное значение не только для Школы. Основные сводки ежедневно по телеграфу приходили из Тифлисской Обсерватории.

В связи с неожиданным прибытием новой группы офицеров-летчиков в Бакинскую школу морской авиации (число офицеров превысило 30 чел), возникла срочная потребность в кают-компании большего размера и вследствие срочного решения этого вопроса А. А. Янович просил Бакинскую городскую управу (14 декабря 1915 г № 396) отвести баржу клуба Торгового флота для нужд школы [48, л. 18]. Со стороны совета старейшин клуба Торгового флота, как отмечалось в письме в Бакинскую городскую управу (19 октября 1916 №383), «препятствий для отвода баржи нет, в случае же повреждений при переводе баржи совет старейшин принимает расходы на себя» $[48$, л. 48$]$.

На необходимые работы для нужд авиационной школы Бакинская городская управа израсходовала 17500 руб., из них 7500 руб. ушло на расширение бывших Деревянной и Таможенной пристани. Однако для погашения этого аванса от начальника школы никаких денег не поступало, хотя требования от него на различные материалы для нужд школы продолжали поступать» [48, л.19]. В силу того, что город не располагал свободными средствами, а расходы по смете 1915 г превысили доходы, Дума постановила прекратить в дальнейшем оплату счетов Бакинского отделения офицерской школы морской авиации, а расход на расширение пристани отнести на счет города. В другом письме Бакинская городская управа (11 января 1916 г. №751) на имя начальника БООШМА сообщала, что «Городская управа, не имея в своем распоряжении свободных наличных средств, отказывается от дальнейших ассигнований, хотя готова предоставить своих техников, но исключительно за счет самой школы» [11, л. 22-22 об.].

В ответном писыме (14 января 1916 г. №121) на имя городского головы г. Баку Л. Л. Быча А. А. Янович сообщал о «завершении работ по оборудованию для нужд школы за счет расширения Каменной и Таможенной пристаней, а также и о том, что школа не имеет никаких особых работ, требующих больших расходов, о том, что отдел воздушного флота... готовит экстренно, с большими трудностями, защитников родины» [11, л. 23]. При этом указывалось, что вся авиационная деятельность не подлежит оглашению [11, л. 23 об.].

В письме, адресованном зав. строительной частью Бакинской городской управы М. Гаджинскому (16.1.1916 г. № 162), А. А. Янович сообщал, что в случае «если город не сможет принять на себя расходы столярных работ и проведение электроосвещения, то стоимость оставшихся работ будет им возмещена городу» [11, л.23об.].

С просьбой о проведении освещения Бакинская городская управа 21 января 1916 года обратилась к Акционерному обществу «Электрическая сила» [11, л. 25]. Также был подготовлен членом управы М. Гаджинским доклад об отводе Каменной пристани и прилегающего к ней про- 
странства для устройства на них ангаров и других сооружений. Городская дума постановила отвести для нужд школы Каменную и Деревянную (бывшую Таможенную) пристани напротив бульвара, выделив на засыпку до 45 тыс. руб. в кредит [12, л. 4 об. -5$]$.

В письмах начальника Бакинского торгового порта А. Данилова (30 октября 1915 г. № 6068 31.10.1915 г. № 6076) на имя начальника Бакинского отделения офицерской школы морской авиации сообщалось об отсутствии препятствий со стороны управления порта к приспособлению для нужд школы Старо-Таможенной пристани [12, л. 5 7]. 25 ноября 1915 г. Бакинская городская управа просила (№ 21339) руководство Торгового порта утвердить смету на засыпку и устройство ограждения, а также расценочную ведомость $[12$, л. 99 об.]. Смета на устройство бетонной дорожки на Каменной пристани для авиационной школы составила 637 руб. 50 коп. [12, л.10], а исполнительная смета на оборудование Каменной пристани для школы составила 7437 руб.13 коп. [11, л. 26 $27,29]$. Сама Таможенная пристань была отделена от бульвара полосой водного пространства (326,50 кв. саж) [11, л. 16]. Исполнительная смета на расширение Таможенной пристани составила 7983 руб., а смета на оборудование Таможенной пристани для авиационной школы - 3 тыс. руб. $[11$, л. 26, 27]. Расходы Городской управы по оборудованию школы составили 10734 руб., о чем позже было отмечено в докладе Бакинской городской управы от 9 фревраля 1916 г (прил. № 9) [11, л. 26].

7 октября 1916 г. состоялось закрытое заседание Бакинской городской думы (журнал № 28), на котором был рассмотрен вопрос об отводе места для авиационной школы [12, л. 16]. В докладе Городской Управы «Об отводе места под Авиационную школу» отмечалось, что "устройство и нахождение школы вблизи Приморского бульвара... небезопасно для многочисленной, посещающей бульвар, публики. Бульвар являлся единственным в городе местом отдыха для публики а занятие школой единственных, оставшихся в распоряжении города для общего пользования, Таможенной и Каменной пристаней стеснило развитое каботажное судоходство.

Согласно архивным данным, наиболее удобным местом для устройства школы являлись участки земли, расположенные на территории Военного порта, а именно: бечевник (береговая полоса, полоса суши вдоль берегов водных объектов общего пользования) против Баиловского шоссе, начиная приблизительно от баркасной пристани общества «Кавказ и Меркурий» к северо-востоку вдоль берега» [12, л. 16]. При этом отмечалась незначительная ширина существующего бечевника, но вследствие небольшой глубины моря представлялось возможным в короткий срок и при сравнительно незначительных затратах образовать сухую территорию достаточных для школы размеров [12, л. 16]. Другим подходящим местом Комиссия признала участок, занятый на тот момент опреснителем.
Оба указанных участка принадлежали Военному порту, следовательно, городское самоуправление могло рекомендовать эти участки. В пределахже городскихвладений сколько-нибудь подходящих свободных участков совершенно не было [12, л. Зг об.]. До этого школа занимала участок на Каменной и Деревянной пристани. Поэтому вопрос расширения этой площади, которую занимала школа, Комиссия, осмотрев этот участок, единогласно пришла к выводу о полной непригодности этого места для устройства авиационной школы. Закрытие двух пристаней, третья Петровская была занята Таможенным и Военным ведомствами - ставило в крайне затруднительное положение каботажное судоходство, а близость этого места с городским бульваром создавало целый ряд больших неудобств, как для населения, так и для школы $[12$, л. 3].

Постоянную угрозу для населения представляли учебные полеты, не гарантирующие от несчастных случаев. Так, подобный случай был в 1915 году, тогда, к счастью, все обошлось без печальных последствий для населения, благодаря тому, что была дождливая погода, и на бульваре никого не было. Поэтому такое соседство для школы признавалось неудобным. Отмечалось, что если школа останется на прежнем месте и на долгий срок, тогда для нее необходима большая площадь, чем она занимала, хотя расширяться было некуда. В этой связи Комиссия категорически высказалась за немедленное перенесение школы с данного района. Но, учитывая тот факт, что для этого потребуется несколько месяцев, в течение которых «школа вынуждена будет закрыться, что, конечно, было нежелательным, Комиссия предложила дать отсрочку на время войны - не более 1 года» [12, л. 3д].

Бакинская Городская Дума, признавая все неудобства, стесненное расположение школы вблизи бульвара, занятие городских пристаней общего пользования и желая пойти навстречу скорейшему открытию и устройству школы, постановила отвести во временное (не более, чем на 1 год) пользование школы Каменную пристань с прилегающим к ней водным пространством до пристани части бывшего о-ва «Надежда» и до пристани Товарищества «Ислам». Кроме того, предлагалось эту половину засыпать частью до глубины в 2-3 фута, а на остальной части устроить платформу на сваях. Таким образом, площадь составила бы в 450 кв. саж. Поэтому представитель Авиационной школы заявил, что если такая площадь будет присоединена к площади Каменной пристани, то школа «освободит деревянную Таможенную площадь, и вовсе не будет занимать бечевник против бульвара вплоть до Каменной пристани» [12, л. 3]. Комиссия, сочтя данный вариант наилучшим решением вопроса, и предложив Думе остановиться на нем, как на временном месте школы, постановила:

- поручить Городской Управе совместно с избранной Городской Думой (заседание от 4.10. 1916 г.) комиссией выработать (с правомочным 
представителем в г. Баку «Отдела воздушного флота, высочайше утвержденного Особого комитета по усилению военного флота на добровольные пожертвования») соглашение относительно временного предоставления школе указанного места и непременного освобождения его от всех сооружений школы по истечении годичного срока со дня постановления Думы;

- разрешить Городской Управе израсходовать для приспособления под школу отводимого водного пространства, ассигнованные по ст. 170 сметы расходов 1916 года, на засыпку береговой полосы 38.397 руб. 60 коп. [12, л. За об.]

Для решения данного вопроса Думой была избрана Особая комиссия из гласных (Ф. Ф. Скрепинского, А. Г. Тагиева и др.) совместно с Управой и с участием начальника Торгового порта и представителя школы. 5 октября 1916 года Комиссия провела осмотр портовой территории для устройства на ней Авиационной школы. Была осмотрена часть от Каменной пристани до Адмиралтейства, другая часть к Белому городу осмотру не подвергалась в виду ясной непригодности для данной цели (имелись в виду сильные волнения во время южных ветров) [12, л. За об.].

Лицам, имевшим образование, окончание военных авиационных школ военного времени давало присвоение воинского звания «прапорщик». Таким образом, авиационные школы в условиях войны отчасти совместили в себе функции учебных заведений двух образовательных уровней: офицерских школ и военных училищ. Совпадение по времени зарождения авиации в России с её участием в первой Мировой войне на многие последующие годы предопределило военный акцент в функционировании всей отечественной авиации в целом [52, с. 530].

Созданные в годы войны базы для подготовки кадров морской авиации позволили в ходе кампании 1917 года начать осуществление целенаправленной и качественной подготовки летного и технического состава для авиационных организационных структур флота в самом морском ведомстве [10]. Наиболее крупной авиашколой к началу 1917 г. на Кавказе стала Кавказская военная авиационная школа в Тифлисе для подготовки летчиков сухопутной авиации (октябрь, 1916г.), преобразованная из довоенной авиашколы Кавказского аэроклуба, где одновременно обучалось около 80 человек в наборе.

Повышению уровня подготовки морских авиаторов способствовал ряд мер организационного характера. В морские авиационные школы в качестве инструкторско-преподавательского состава с флотов направлялись наиболее подготовленные специалисты, были установлены квалификационные требования к выпускникам морских авиационных заведений по специальностям летчика, наблюдателя и авиационного механика, внесены соответствующие изменения в программы подготовки специалистов для морской авиации разной направленности. Таким образом, в годы первой Мировой войны в составе отечественного фрлота был создан в конце 1916 - начале 1917 гг. новый род вооруженных сил - морская авиация.

10 июля 1917 года в Москве открылся Первый Всероссийский авиационный съезд, избравший Всероссийский авиационный Совет, утвержденный приказом военного министра генерал-майора А. И. Верховского, в который вошли в основном офицеры. Эту общественную организацию с непонятным статусом, но большими амбициями возглавил летчик-наблюдатель член партии эсеров поручик Д. Д. Хризосколео. Однако, по словам Е. И. Ахматовича, этот орган «не внес ничего существенного в положение, создавшееся в авиационных войсках, и своей нераспорядительностью он только способствовал росту недовольства в солдатских массах, и, в конце концов, такое состояние привело к гибели этого «авторитетного» органа» [4, с. 3-19].

Однако вопросы подготовки авиационных кадров становились актуальными и были рассмотрены вскоре на Втором авиационном съезде, состоявшемся в Москве 15 июня 1918 г. В решениях съезда было отмечено, что создание Воздушного флота в России зависит от уровня развития авиатехники и промышленности, для чего необходимо было поднять уровень кадров, сосредоточенный в технических учебных заведениях. Для этой цели съезд признал необходимым учреждение высшего авиационного института, среднего авиатехникума при МВТУ, согласно проекту профессора Н. Е. Жуковского, поручив ему это [19, с. 19-24].

С образованием 28 мая 1918 г. Азербайджанской Демократической Республики (АДР) - первого демократического государства на Востоке одной из первых мер, предпринятых молодым государством, стало создание военно-воздушных сил страны. В этой связи одной из приоритетных задач государство считало подготовку кадров в сорере авиации, чем и занялось созданное Военное министерство, возглавляемое генералом Caмед беком Мехмандаровым.

Толчком к развитию авиационной политики АДР стал подписанный в 1919 году между Азербайджаном и Грузией договор о сотрудничестве в военной сфере, поскольку Грузия в то время являлась своего рода плацдармом России и центром военных структур, и в частности, учебных заведений в области авиации. Приказом 19 августа 1919 г. за подписью генералов Самеда бека Мехмандарова и Мамед бека Сулькевича подпоручик Теймурхан Афшар был назначен заместителем начальника авиаотряда при Генштабе Азербайджанской армии [46, с. 30]. С этого времени была начата работа по созданию новой структуры. 14 сентября 1919 года военным министром был утвержден штат авиаотряда $[46$, с.30]. По приказу военного министра и, согласно подписанному договору, для практической подготовки в Грузию была отправлена группа в составе солдат и офицеров Азербайджана из 9 человек. Окончившие 3-х месячные курсы в Авиационном училище в Тифлисе они вернулись в Азербайджан и среди них прапорщики: Алигусейн Дадашев, Теймур Мустафаев, Гянджинский, Ахмедали Аждар 
Гасанзаде, Мамед Гарашаров Асад Алиев, капитан Фиридун бек мирза Сейфрулла оглу Гаджар и другие $[23,11 ; 46$, с. 30$]$.

Правительство АДР обеспечивало полеты самолетов. Так, например, уже в 1919 году впервые в истории авиации Азербайджана был осуществлен перелет через Каспийское море на самолете «Фарман-30», удачно приземлившийся в городе Красноводск (Туркменистан). Правительство Азербайджана приступило к организации национальных вооруженных сил. Было принято решение о создании в армии Азербайджанской Демократической Республики военного авиационного отряда. 26 января 1920 г. по приказу заместителя военного министра Алиаги Шихлинского началось создание в азербайджанской армии 1-го военного авиационного отряда и военно-морской школы летчиков. На должность командира назначили Граудин-Граудса, а коммуниста шведа Гарри Флекмооре (до революции работал в цирке, а весной 1920 г. стал директором Бакинского цирка) военным комиссаром. Заместителем военкома был утвержден С. А. Красовский [43 с. 46]. Из Москвы прибыли машины отечественного производства «Лебедь-12» и «Ньюпор-17». По словам С. А. Красовского, в тот период нелегко было организовать ремонт и эксплуатацию самолетов. Объяснялось это тем, что в Азербайджане не было ни авиазавода, ни авиа-мастерских. Техническое имущество, детали, шплинты и гайки приходилось добывать на частном рынке, и только в централизованном порядке из Гянджи, со складов республики, привозили пулеметы.

Авиационная политика Азербайджанской Демократической Республики, к большому сожалению, была прервана приходом в апреле 1920 года в Баку XI Красной Армии, свергнувшей Правительство АДР и установившей советскую власть. C этого времени азербайджанская гражданская авиация начала функционировать уже в составе СССР. Но, несмотря на ряд ограничений, с которыми пришлось столкнуться азербайджанской авиации, она смогла добиться определенных успехов. В 1924 году во время одного из полетов на самолете М-9 первый советский военный летчик-азербайджанец Теймур Мустафаев и летный наблюдатель Гаджиев обнаружили в Каспийском море нефтяные фонтанчики [43, с. 54-55].

Важным событием в жизни авиации Азербайджана стало строительство аэропортов в Бина (1930-33), Евлахе (1932), Аджикабуле, Шеки (1933). Дпя строительства и оборудования воздушных линий местного значения правительством СССР было выделено 50 млн руб. [16, с. 70-71]

Примечательным в истории авиации Азербайджана событием стало появление первой азербайджанской летчицы - Соны Нуриевой, окончившей летное училище в Батайске. Ее примеру последовали Зулейха Сеидмирзоева и Лейла Мамедбекова [1, с. 53-54; 45, с. 4].

Однако ситуация в стране была неспокойной. В 1928 году весь конструкторский отдел по гидросамолетам, возглавляемый Д. П. Григоровичем, был отправлен в Бутырскую тюрьму. Здесь под его руководством совместно с авиаконструктором Н. Н. Поликарповым было создано первое в истории тюремное конструкторское бюро и спроектирован истребитель с двигателем воздушного охлаждения [42, с.138-139; 51, с. 49].

В годы Второй мировой войны многие азербайджанские летчики были удостоены звания Героя Советского Союза. Но это уже совершенно другая история.

Подытоживая, отметим, что созданием Бакинского отделения офицерской школы морской авиации было положено начало авиационному образованию в Азербайджане. Пятимесячный учебный период в Баку прошел в целом спокойно и плодотворно. В этом, несомненно, заслуга не только первого начальника Бакинской Школы морской авиации капитана 1-го ранга А. А. Яновича, но Бакинской Городской думы и Бакинской городской управы, много сделавших для успешной работы Школы в подготовке морских летчиков (к уже выпущенным Школой, было подготовлено еще 15 почти готовых морских летчиков, которые самостоятельно вылетели из Баку в Петроград). С 25 февраля 1917 г. Бакинское отделение стало Бакинской школой морской авиации [5, с. 4; 7], 100-летний юбилей которой был отмечен в 2017 г В итоге - обе школы в Петрограде и Баку стали существовать самостоятельно.

Постановлением Кабинета Министров Азербайджанской республики от 15 июня 1992 года № 337 в целях создания необходимых условий для подготовки, повышения квалификации и переподготовки авиационных кадров учебно-тренировочный центр (УТЦ) по повышению квалификации и переподготовки кадров Государственного Концерна «Азербайджан Хава Йоллары» был преобразован в Национальную Академию Авиации (НАA) - государственное высшее учебное заведение Азербайджанской Республики, занимающееся подготовкой, повышением квалификации и переподготовкой авиационных кадров, первый выпуск (80 чел.), который состоялся в 1996 году. В НАА имеется современная электронная библиотека, а также книжный фонд, укомплектованный научно-технической, учебно-методической, справочной и специальной литературой. Библиотечный фонд постоянно обновляется и пополняется.

29 фревраля 2008 г. в Национальной Академии Авиации состоялось торжественное открытие Музея Гражданской Авиации, целью и задачей которого является поиск, сбор, изучение, сохранение материалов, отражающих историю авиации Азербайджана. Экспозиция Музея Гражданской Авиации ярким образом отражает пути развития азербайджанской авиации, а также пройденные национальными авиаторами этапы. В настоящее время в основном и вспомогательном фондах Музея гражданской авиации в надежных условиях хранятся свыше 6000 весьма редких музейных материалов. 


\section{Источники и литература}

1. Алиев Г. Транспорт и экономика Азербайджана (первая половина XX века). Баку: Элм. 2001. 244 с

2. Алиев Н. Соколы Азербайджана: [Об истории авиации Азербайджана]. Баку: Азернешр, 1979. 212 с.

3. Алиева Л.А. Положение женщин Азербайджана в период военных конфликтов (на примере фактов । Мировой войны) // Baki universitetinin xәbərləгі. Humanitar elmlər seriyası. 2012. №4. C.87- 88.

4. Ахматович Е.И. В первые дни // Шипилов И.Ф. Звезды на крыльях: воспоминания ветеранов советской авиации М.: Воениздат, 1959. С.3-19.

5. Ахундов Ф. Короли моря и воздуха // Азербайджанские известия. 2006. 22 декабря

6. Баку. 1910. 20 октября.

7. Баку. 1916, 5 января.

8. Баку. 1916, 16 февраля.

9. Беляков А. И. Санкт-Петербург - родина морской авиации // Морской сборник. 2000. №8. С.62 - 67

10. Герасимов В. Л. Отечественная морская авиация в Первую мировую войну: дис. ... канд. ист. наук. М.: Институт военной истории Министерства обороны Российской Федерации. 2004, 306 с.

11. Государственный Исторический Архив Азербайджанской Республики (далее - ГИА АР): Ф. 46. ОП. 4. Д. 522

12. ГИА АР: Ф.389. Оп. З. Д. 2971

13. ГИА АР: $Ф .485$. Оп.1. Д.34

14. ГИА АР: Ф.485. Oп.1. Д.35

15. ГИА АР: Ф.485. Оп.1. Д.39

16. Гражданская авиация СССР. 1917-1967гг. / отв. ред. Безбородов Г. В. М.: Транспорт, 1967. 317 с

17. Гусейнов А. Азербайджанцы в истории России. М.: Оверлей, 2006. 562 с.

18. Гусейнова Д. С. Развитие морского транспорта, формирование кадров рабочих-моряков Азербайджана и их революционные выступления (90-е годы 19 в. - 1907): автореф. дис. ... канд. ист. наук. Баку: [б. и.], 1975. 38 с.

19. Елисеев С. П. Сохранить все авиационные школы для трудового народа. Влияние Великой Октябрьской социалистической революции на систему подготовки военных авиационных кадров в Советской России. К 100-летию отечественного Военно-воздушного флота // Военно-исторический журнал. 2012. №7. С.19-24

20. Известия Бакинской городской думы. 1916. Октябрь-ноябрь. №10-11.

21. Известия Бакинской городской думы. 1917. Январь-март. №1-3.

22. Исмаилов Э. Георгиевские кавалеры-азербайджанцы. М.: Герои Отечества, 2005. 247 с.

23. История авиации в Азербайджане. Библиография материалов на русском языке. Сост. Ш. Ахундов. Баку: [б. и.], 2012. $280 \mathrm{c}$

24. Кавказ. 1916. 28 февраля

25. Кавказский календарь на 1914 год. Тифлис: Гл. упр. Кавказ. наместника, 1913. 977 с.

26. Кавказская копейка. 1915. 22 ноября. № 323.

27. Кавказская копейка. 1915. 28 ноября. № 329

28. Кавказская копейка. 1915. 14 декабря. № 345

29. Кавказская копейка. 1915. 15 декабря. № 346

30. Кавказская копейка. 1915. 16 декабря. № 347

31. Кавказская копейка. 1916. 5 января. № 5

32. Кавказская копейка. 1916. 12 января. № 12

33. Кавказская копейка. 1916. 16 февраля. № 47

34. Кавказская копейка. 1916. 28 февраля. № 59

35. Кавказская копейка. 1916. 12 марта. № 72

36. Каспий. 1915. 24 ноября. № 262

37. Каспий. 1915. 25 ноября. № 263

38. Каспий. 1915. 26 ноября. № 264

39. Каспий. 1916. 14 февраля. № 36

40. Каспий. 1916. 16 февраля. № 37

41. Каспий. 1916. 25 февраля. № 44

42. Керимова Э. А. Азербайджанская авиация в период предвоенного десятилетия // Tarix və onun problemləri. 2010. №1. С.138-139.

43. Красовский С. А. В Закавказье // Жизнь в авиации. М.: Воениздат, 1968. 374 с

44. Краткий обзор истории авиации в российском императорском флоте (1890-1917). URL: http://xx/3.ru/kadeti/rus_ mor_avia.htm; http://www.migavia.com/articles/rus-mor-avia.html. (Дата обращения: 20.11.2018).

45. Лифшиц Г. Знатные лётчицы Азербайджана: [Производственные биографии летчиц - парашютисток Лейлы Мамедбековой, Зулейхи Сеидмамедовой и Соны Нуриевой] // Самолёт. 1936. №3. С.4

46. Назирли Шамистан. Соколы первой республики: [1 4 сентября 1919 года Военный министр Азербайджанской Республики издал приказ о создании в армии авиаотряда] // Шамистан. Первый военный лётчик Азербайджана Фаррух ага Гаибов. Баку: CBS Polyqraphic Production, 2007. C.29-35.

47. Наше Слово. 1916. 13 марта

48. Российский Государственный Архив Военно-Морского Флота (далее - РГА ВМФ). Ф. 417. Оп. 2. Д. 1252.

49. РГА ВМФ. Ф. 418. Оп.1. Д. 2104.

50. РГА ВМФ. Ф. 1230. ОП.1.Д. 7.

51. Соболев Д.А. Репрессии В советской авиапромышленности // Вопросы истории естествознания и техники. 2000. №4. C.49.

52. Тимофеев Ф. Д. Подготовка летчиков в военно-учебных заведениях России и в начале XX века // Известия российского государственного педагогического университета им. А.И. Герцена. 2007. Т.16. Вып. № 40. С. 527-530. 
53. Филс С. Страницы Истории Морской Авиации России: БОШМА. ЧАСТЬ V: Кое-что еще о происшествиях, учебе и жизни школы URL: http://www.proza.ru/2011/08/14/215 (Дата обращения: 7.04.2018).

54. Şahbazi Tağı. Yeni əhval qarşısında qadınlarımız // Açıq söz) qəzeti. 1916. 4 avqust. №250.

\section{References}

1. Aliev G. Transport i jekonomika Azerbajdzhana (1 pol. XX veka) (Transport and Economy of Azerbaijan (1st half of the twentieth century). Baku: Jelm. 2001. 244 p. (In Russian).

2. Aliev N. Sokoly Azerbajdzhana: [Ob istorii aviacii Azerbajdzhana] (Falcons of Azerbaijan: [On the history of aviation in Azerbaijan]). Baku: Azerneshr, 1979. 212 p. (In Russian).

3. Alieva L. A. Polozhenie zhenshhin Azerbajdzhana v period voennyh konfliktov (na primere faktov I Mirovoj vojny) (The Position of the Women of Azerbaijan in the Period of Military Conflicts (With the Reference to the Facts of World War I) // Baki universitetinin xəbərləri. Humanitar elmler seriyası. 2012. No. 4. P. 87-88. (In Russian)

4. Ahmatovich E. I. V pervye dni (In the Early Days) // Shipilov I.F. Zvezdy na kryl'jah: vospominanija veteranov sovetskoj aviacii. M.: Voenizdat, 1959. 312s. Moscow: Voenizdat, 1959. P.3-19. (In Russian).

5. Ahundov F. Koroli morja i vozduha (Kings of the Sea and Air) // Azerbajdzhanskie izvestija. 2006. December 22. (In Russian).

6. Baku. 1910. October 20. (In Russian)

7. Baku. 1916. January 5. (In Russian)

8. Baku. 1916. February 16. (In Russian).

9. Beljakov A. I. Sankt-Peterburg - rodina morskoj aviacii (St. Petersburg - the Birthplace of Naval Aviation) // Morskoj sbornik. 2000. No. 8. P. 62-67. (In Russian).

10. Gerasimov V. L. Otechestvennaja morskaja aviacija v Pervuju mirovuju vojnu (National Naval Aviation in the First World War): thesis. Moscow, 2004. 306 p. (In Russian).

11. State Historical Archive of the Republic of Azerbaijan (GIA AR): F. 46. Inv. 4. D. 522. (In Russian)

12. GIA AR: F.389. Inv. 3. D. 2971. (In Russian).

13. GIAAR: F.485. Inv.1. D.34. (In Russian).

14. GIAAR: F.485. Inv.1. D.35. (In Russian)

15. GIAAR: F.485. Inv.1. D.39. (In Russian).

16. Grazhdanskaja aviacija SSSR 1917-1967gg. (Civil Aviation of the USSR. 1917-1967). Moscow: Transport, 1967. $317 \mathrm{p}$. (In Russian).

17. Gusejnov A. Azerbajdzhancy v istorii Rossii (Azerbaljanis in the History of Russia). Moscow: Overlej, 2006. 562 p. (In Russian).

18. Gusejnova D. S. Razvitie morskogo transporta, formirovanie kadrov rabochih-morjakov Azerbajdzhana i ih revoljucionnye vystuplenija (90-e gody 19 v. - 1907) (The Development of Maritime Transport, the Formation of the Staff of Seafarers in Azerbaijan and Their Revolutionary Demonstrations (the 90s of the 19th century - 1907): abstract of thesis. Baku, 1975. 38 p. (In Russian).

19. Eliseev S. P. Sohranit' vse aviacionnye shkoly dlja trudovogo naroda. Vlijanie Velikoj ktjabr'skoj socialisticheskoj revoljucii na sistemu podgotovki voennyh aviacionnyh kadrov v Sovetskoj Rossii. K 100-letiju otechestvennogo Voennovozdushnogo flota (Save All Aviation Schools for Working People. The Influence of the Great October Socialist Revolution on the System of Training Military Aviation Personnel in the Soviet Russia. On the 100th Anniversary of the National Military Air Fleet) // Voenno-istoricheskij zhurnal. 2012. No. 7. P. 19-24. (In Russian).

20. Izvestija Bakinskoj gorodskoj dumy. 1916. October - November. No. 10-11. (In Russian)

21. Izvestija Bakinskoj gorodskoj dumy. 1917. January - March. No. 1-3.

22. Ismailov Je. Georgievskie kavalery-azerbajdzhancy (George Knight's - Azerbaijanis). Moscow: Geroi Otechestva, 2005. 247 p. (In Russian).

23. Istorija aviacii $\vee$ Azerbajdzhane. Bibliografija materialov na russkom jazyke (History of Aviation in Azerbaijan. Bibliography of Materials in Russian). Baku, 2012. 280 p. (In Russian).

24. Kavkaz. 1916. February 28. (In Russian).

25. Kavkazskij kalendar' na 1914 god. Tiflis: Headquarters of the Caucasian governor, 1913, 977 p. (In Russian).

26. Kavkazskaja kopejka. 1915. November 22. No. 323 (In Russian)

27. Kavkazskaja kopejka. 1915. November 28. No. 329. (In Russian).

28. Kavkazskaja kopejka. 1915. December14. No. 345. (In Russian).

29. Kavkazskaja kopejka. 1915. December 15. No. 346. (In Russian).

30. Kavkazskaja kopejka. 1915. December 16. No. 347. (In Russian).

31. Kavkazskaja kopejka. 1916. January 5. No. 5. (In Russian).

32. Kavkazskaja kopejka. 1916. January 12. No. 12. (In Russian).

33. Kavkazskaja kopejka. 1916. February 16. No 47. (In Russian).

34. Kavkazskaja kopejka. 1916. February 28. No. 59. (In Russian)

35. Kavkazskaja kopejka. 1916. March 12. No. 72. (In Russian).

36. Kaspij. 1915. November 24. No. 262. (In Russian).

37. Kaspij. 1915. November 25. No. 263. (In Russian).

38. Kaspij. 1915. November 26. No. 264. (In Russian).

39. Kaspij. 1916. February 14. No. 36. (In Russian).

40. Kaspij. 1916. February 16. No. 37. (In Russian)

41. Kaspij. 1916. February 25. No. 44. (In Russian).

42. Kerimova Je. A. Azerbajdzhanskaja aviacija v period predvoennogo desjatiletija (Azerbaljan Aviation during the Prewar Decade) // Tarix və onun problemləri. 2010. No. 1. P.138-139. (In Russian). 
43. Krasovskij S. A. V Zakavkaz'e / Zhizn'v aviacii (In Transcaucasia / Life in Aviation). Moscow: Voenizdat, 1968. 374 p. (In Russian).

44. Kratkij obzor istorii aviacii v rossijskom imperatorskom flote (1890-1917) (A Brief Overview of the History of Aviation in the Russian Imperial Fleet (1890-1917). URL: http://xxl3.ru/kadeti/rus_mor_avia.htm; http://www.migavia.com/articles/rusmor-avia.html. (Accessed: 20.11.2018). (In Russian).

45. Lifshic G. Znatnye ljotchicy Azerbajdzhana: [Proizvodstvennye biografii letchic - parashjutistok Lejly Mamedbekovoj, Zulejhi Seidmamedovoj i Sony Nurievoj] (Notable Pilots of Azerbaijan: [Biographies of Female Pilots - Parachutists of Leyla Mamedbekova, Zuleikha Seyidmamedova and Sona Nurieva]) // Samoljot. 1936. No. 3. P.4. (In Russian).

46. Nazirli Shamistan. Sokoly pervoj respubliki: [14 sentjabrja 1919 goda Voennyj ministr Azerbajdzhanskoj Respubliki izdal prikaz o sozdanii v armii aviaotrjada] (The Falcons of the First Republic: [On September 14, 1919, the Minister of War of the Republic of Azerbaijan Issued an Order Establishing an Squadron in the Army]) // Shamistan. Pervyj voennyj ljotchik Azerbajdzhana Farruh aga Gaibov. Baku: CBS Polyqraphic Production, 2007. P.29 - 35. (In Russian).

47. Nashe Slovo. 1916. March 13. (In Russian)

48. Russian State Archive of the Navy (RGA VMF). F. 417. Inv. 2. D. 1252. (In Russian).

49. RGA VMF. F. 418. Inv.1. D. 2104. (In Russian)

50. RGA VMF. F. 1230. Inv.1. D. 7. (In Russian).

51. Sobolev D. A. Repressii v sovetskoj aviapromyshlennosti (Repression in the Soviet Aircraft Industry) // WIEET. 2000. No. 4. C.49. (In Russian).

52. Timofeev F. D. Podgotovka letchikov v voenno-uchebnyh zavedenijah Rossii i v nachale XX veka (Training of Pilots in Military Schools of Russia and at the Beginning of the Twentieth Century) // Izvestija rossijskogo gosudarstvennogo pedagogicheskogo universiteta im. A.I. Gercena. 2007. Vol.1 Issue 6. No. 40. P. 527-530. (In Russian).

53. Fils S. Stranitsy Istorii Morskoi Aviatsii Rossii: BOShMA. Part.' V: Koe-Chto eshche O Proisshestviiakh, Uchebe iZhizni Shkoly - http://www.proza. ru/2011/08/14/215 - data obrashcheniia 7 aprelia $2015 \mathrm{~g}$ (Pages History of Naval Aviation of Russia: BOSHMA. PART V: Something More About Accidents, Learning and School Life) URL: http://www.proza.ru/2011/08/14/215 (Accessed: 7.04.2018). (In Russian).

54. Şahbazi Tağı. Yeni ahval qarşısında qadınlarımız // Açıq söz» qəzeti. 1916. August 4. No. 250. (In Russian)

Сведения об авторе

Вагабова Эсмира Рагим Гызы - доктор философии по истории, ведущий научный сотрудник Института истории им. А. А. Бакиханова НАН Азербайджана (Баку, Азербайджан) / esmira.vahabova@ mail.ru

Information about the author

Vagabova Esmira - Dr. of Historical sciences, Leading researcher, Institute of History named after A. A. Bakikhanov, Azerbaijan National Academy of Sciences (Baku, Azerbaijan) / esmira.vahabova@mail.ru 